\title{
Elizabeth (Liz) Eckermann: A Pioneer in Gendered Understandings of Quality of Life
}

\author{
Elizabeth Eckermann ${ }^{1}$
}

Received: 13 July 2015 / Accepted: 30 July 2015 / Published online: 7 August 2015

(C) Springer Science+Business Media Dordrecht and The International Society for Quality-of-Life Studies

(ISQOLS) 2015

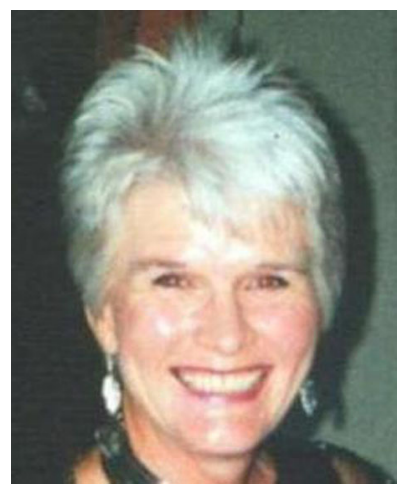

I feel like I was there even before the baby was conceived! The setting was the University of Northern British Columbia, Prince George, August 1996, amongst the bears, the salmon, the cougars and a potpourri of sociologists, psychologists, economists, political scientists and demographers from the furthest ends of the earth. Why did so many of us down tools in our home states and travel half way across the world to meet together to explore new fields of research at the first World Conference on Quality of Life initiated by the grand old daddy of quality of life, Alex Michalos? In a sense we were all pilgrims chasing the holy grail of transforming indicators of wellbeing and searching out new ways of measuring progress. I know I came to find like-minded researchers to help me solve some problems with developing gender sensitive quality of life indicators for a consultancy I was contracted to do for the World Health Organization after the UN World Conference on Women in Beijing in 1995. Alex

Elizabeth Eckermann

liz.eckermann@deakin.edu.au

1 Faculty of Arts and Education, Deakin University, Geelong 3217, Australia 
drew us to the flame and little did we know that the light was in fact a glint in his eye which was to blossom into the International Society for Quality of Life Studies (ISQOLS).

The pilgrimage continues as this disparate band of pioneers with failing health, greying hair and unsteady gait still transports themselves across the world at regular intervals to thrash out quality of life dilemmas and conundrums at the ISQOLS conferences. I am very proud to be one of them! But how on earth did I get so lucky to regularly spend my time with such an inspiring bunch of people? No doubt the seed was planted in childhood.

I grew up on the island of Borneo surrounded by coral reefs, monkeys, orang utans, crocodiles and hornbills. As the daughter of very busy parents (my father was Director of Lands and Surveys and my mother the Head of St John Ambulance), I was brought up by Malay and Kadazan amahs. They imbued in me a passion for the multiple cultures of Borneo including a respect for nature, for community and for the spirit world. At eight years old I was sent to boarding school in Australia and learnt an alternative worldview including strategies to defy authority and hone my skills as a budding private detective. After six years at boarding school, seeing my parents for only a few weeks once a year, the headmistress suggested that some family discipline may not go astray, so I returned to Sabah College in Borneo (by then part of Malaysia) to complete my schooling.

Sabah had no tertiary institutions at the time, so in 1966 it was back to Australia to attend university. At Flinders University in South Australia I did an Honours degree in Sociology, followed by a Masters degree in Political Sociology, then a Doctorate in Medical Sociology and taught first in a secondary college and then at various universities. Meanwhile, I was married and had two beautiful children. I started my research career at the South Australian Film Corporation in 1975 conducting the background research for films on women's health and wellbeing, while completing my honours thesis on political cartooning. Like many of the baby boomer generation women, my life involved juggling full-time work, part-time study and full-time parenting given the dearth of quality child-care and after-school-care facilities in the 1970s. I have been juggling ever since with grandchildren in the mix too!

One advantage of multi-tasking is that you adjust to holding a multiplicity of passions, interests and engagements simultaneously and my research activities and publications reflect this eclectic mix. Over the past five decades my key areas of research interest, research funding, consultancy and publication have spanned political sociology, medical sociology, sociology of the body, women's health, reproductive health, gender and health, maternal health in Lao PDR, alcohol related harm reduction in Sabah, domestic violence, quality of life and indicators of health status, voluntary self-starvation in girls, health promotion and public health. These research interests may appear disparate, however, the nexus between them lies in the social justice agenda that drives all my research and a deep commitment to women's and girls' empowerment. I am particularly concerned with giving a voice to women who are neither literate nor numerate and letting them tell their story about how fulfilling their lives are. This is the motivation behind the development of the refined version of the Diamond Dialogue tool which I use to evaluate the effectiveness of interventions designed to improve women's lives in Lao PDR and in my home state of Sabah, Malaysia. 
Research for me is the passionate, relentless, rigorous and engaged pursuit of understanding of the factors which lie behind what appears to be. To do this, it is paramount to understand the philosophical, theoretical and empirical dimensions of what propels people to act, including what inspires individuals to get up in the morning and what collectively inspires communities and nations to make the world a better place. Bhutan has addressed these issues systematically in the development of the Gross National Happiness Index, the OECD has taken quality of life onboard in its Better Life Index. The great pioneers of quality of life Alex Michalos, Joe Sirgy, Richard Estes, Ruut Veenhoven, Wolfgang Glatzer, Robert Cummins, Valerie Moller, Anna Lau, Don Rahtz, Kenneth Land, Laura Camfield, Andrew Clark, Ferran Casas, Michael Frisch, Mahar Mangahas, Mariano Rojas, Peggy Schyns, Eduardo Wills Herrera, Filomena Maggino and Ed Diener, amongst others, many of whom were in Prince George in 1996, still 20 years later inspire me and the entire quality of life community.

\section{Selected References}

Eckermann, E. (2015). 'Living alone and living together: Their significance for well-being'. In W. Glatzer (Ed.), Global handbook of quality of life. Netherlands: Springer.

Eckermann, E. (Ed.). (2014). Gender, lifespan and quality of life: An international perspective. London and NY: Springer.

Eckermann, L., Scopaz, A., \& Clarke, M. (2014). 'Quality of life for pregnant and recent parity women in Lao PDR'. In E. Eckermann (Ed.), Gender, lifespan and quality of life: An international perspective. London and NY: Springer.

Scopaz, A., Eckermann, E., \& Clarke, M. (2012). Diamond dialogue method for the evaluation of personal wellbeing after a maternal health intervention in Lao PDR. International Journal of Happiness and Development, 1(1), 49-62.

Eckermann, E. (2012). 'The quality of life of Adults'. In K. C. Land, A. C. Michalos, \& M. Joseph Sirgy (Eds.), Handbook of social indicators and quality of life research (pp. 373-380). Dordrecht: Springer. 